\author{
Journal of Food Technology Research \\ 2022 Vol. 9, No. 1, pp. 46-54. \\ $\operatorname{ISSN}(e): 2312-3796$ \\ $\operatorname{ISSN}(p): 2312-6426$ \\ DOI: $10.18488 /$ iftr.v9i1.2929 \\ (C) 2022 Conscientia Beam. All Rights Reserved. \\ check for
updates
}

\title{
CHARACTERIZATION AND STORAGE STABILITY STUDY OF GUAVA AND MANGO WOOD SMOKED INDUCED SPICED CULTURED MILK (RAITA)
}

Arghya
Chaudhuri $^{1+}$
(iD) Aditya ${ }^{2}$
(i) Himanshu Mishra
(i) Sachin Patidar
(i) Hameedur
Rehman $^{5}$
(D) Lokesh
Choudhary
(iD CTM Kumar

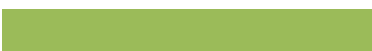

\section{Article History}

Received: 19 November 2021

Revised: 17 January 2022

Accepted: 3 February 2022

Published: 23 February 2022

\section{Keywords}

Raita

Smoking

Guava wood

Mango wood

Smoked food

Smoked dairy products

\author{
${ }_{1,2,9,4,5,6}$ Dairy Technology Division, ICAR-National Dairy Research Institute, \\ Karnal, Haryana, India. \\ 'Email:nvp.kls@gmail.com Tel: 7027704994 \\ ${ }^{2}$ Email: adityarajepur@gmail.com Tel:9466332590 \\ ${ }^{s}$ Email: honeymishra542@gmail.com Tel:9968148322 \\ ${ }^{4}$ Email: sarsachin3111@gmail.com Tel: 7400763713 \\ ${ }^{5}$ Email: myloginidhameed321@gmail.com Tel:6394704151 \\ ${ }^{6}$ Email: lokeshndri6618@gmail.com Tel:7014861186 \\ 'Southern Regional Station, Dairy Technology Section, ICAR-National \\ Dairy Research Institute, Bengaluru, Karnataka, India. \\ 'Email:manojct.ndri@gmail.com Tel:9541310674
}

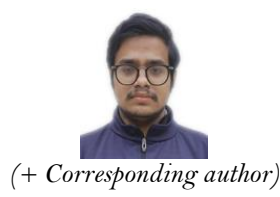

\begin{abstract}
A study was conducted to evaluate the effect of the smoking of raita with guava and mango wood on its functional properties and storage stability. The raita was smoked with guava and mango wood for $2.5,5,7.5$, and $10 \mathrm{~min}$ in a closed chamber. The smoked raita was evaluated for change in titratable acidity (TA), $\mathrm{pH}$, total phenolic content (TPC), antioxidant activity (DPPH), colour ( $\mathrm{L}^{*}$, $\mathrm{a}^{*}$, and $\left.\mathrm{b}^{*}\right)$, and sensory attributes. Both guava and mango wood smoked samples didn't show significant changes $(\mathrm{P}<0.05)$ in TA, $\mathrm{pH}, \mathrm{TPC}$, and antioxidant activity. All colour values ( $\mathrm{L}^{*}, \mathrm{a}^{*}$ and $\left.\mathrm{b}^{*}\right)$ of smoked samples were significantly $(\mathrm{P}<0.05)$ higher than the control sample, particularly, the yellowish attribute ( $\mathrm{b}^{*}$ ) was very high in smoked samples. The sample that smoked for $7.5 \mathrm{~min}$ had very high overall acceptability scores in both kinds of wood and which is considered as an optimum smoking time for raita. The selected raita samples were stored for 9 days at $44^{\circ} \mathrm{C}$ and assessed for $\mathrm{TA}, \mathrm{pH}$, and standard plate count (SPC) at 3 days of interval. During the storage period, a significant reduction $(\mathrm{P}<0.05)$ in $\mathrm{pH}$ and a significant increase $(\mathrm{P}<0.05)$ in TA was seen till the 6th day of storage. The smoked samples had considerably lower SPC than the control sample and SPC was decreased significantly $(\mathrm{P}<0.05)$ with an increase in storage days in all the samples. The preparation is simple and can be served in Pubs/Bars, Casual Dining Restaurants \& QSRs (Quick served restaurants).
\end{abstract}

Contribution/Originality: This study was conducted to improve the characteristics and sensory property of raita. The smoked dairy products are restricted to cheese and whipped cream. This study has expanded the category of smoked dairy product.

\section{INTRODUCTION}

Smoking is a process of penetration of volatiles resulting from the thermal destruction of wood into the surface of food products (Adeyeye, 2019). It is the most common process applied during the processing of fish- and meatbased products. Smoke not only improves colour and flavor but also imparts bacteriocidal and antioxidant properties to food products. The smoke is composed of 1100 chemical compounds with over 400 volatile compounds constituting 
48 acids, 22 alcohols, 131 carbonyls, 75 phenols, 22 esters, 16 lactones, 46 furans, and some 50 miscellaneous compounds (Sunen, 1998). The bacteriocidal and antioxidant properties are due to the presence of thymol, formaldehyde; formic, acetic, and benzoic acids, orthocresol, metacresol, paracresol, guaiacol, methyl guaiacol, and xinelone (Vaz-Velho, 2003). The smoking process can be categorized into cold $\left(28-32^{\circ} \mathrm{C}\right)$ and hot smoking (70-80 $\left.{ }^{\circ} \mathrm{C}\right)$. Cold smoking is commonly used to enhance the flavour and stability against spoilage as well as pathogenic organisms (Alasalvar, Miyashita, Shahidi, \& Wanasundara, 2011). However, cold-smoked products essentially required refrigeration storage except for dry-cured products. The hot smoking process is the combination of three processes cooking, drying, and smoking. The hot smoked products are normally stable at room temperature. The selection of wood is very important in smoking, because, odour, taste, bacteriocidal and antioxidant properties vary with the type of wood (Hui, Nip, \& Rogers, 2001; McGee, 2004). The commonly used wood materials for smoking are coconut shell and husk, sag, paddy husk, apple, guava, mango, rosewood, etc (Adeyeye, 2019). Mango and guava woods are preferred for smoking because they are easily available and commonly used as a source of fuel in many countries. Several works of literature reported the use of both kinds of wood for smoking fish and meat products (Atanda, Adekalu, Agoda, Benson, \& Ihionu, 2015; Da Silva Cardoso et al., 2020; Doe, Dali, \& Harmain, 2020; Margaret \& Edgar, 2016; Obodai, Muhammad, Obodai, \& Opoku, 2009).

Among dairy products, several varieties of cheese are most commonly subjected to smoking. In earlier days, smoking of cheese was to improve the shelf-life, but nowadays smoking is done to achieve differentiation and flavor development (Rehman, Farkye, \& Drake, 2003). Some popular smoked cheeses are Bandal (India), Gamonado (Spain), Oscypek (Poland), and Provolone (Italy) (Majcher, Ławrowski, \& Jeleń, 2010; Rehman et al., 2003). Recently, whipped cream was smoked using liquid smoke to improve the sweetness and caramel flavours (Snow, 2010). Raita is a popular fermented dairy-based condiment consumed in south Asian countries. It is prepared by diluting curd/Dahi with water and often seasoned with Bundi (Tiny balls of fried chickpea flour), sour fruits, roasted cumin, coriander, pepper, salt chili powder, and other herbs and spices. Raita gives a cooling effect on the palate after having heavily spiced dishes. The variety and methodology of preparation of raita differ from region to region. The smoked raita is a novel product that has a better aroma and taste and also has a very high shelf life compared to non-smoked raita.

In the present investigation, the process for the preparation of smoked raita using guava and mango wood was optimized and evaluated for its storage stability. The smoked product was analyzed for change in acidity, pH, colour, total phenolic content, antioxidant activity, sensory and microbiological characteristics.

\section{MATERIALS AND METHODS}

\subsection{Materials}

Buffalo milk was obtained from Experimental dairy, NDRI. The composition of buffalo milk such as total solids, fat, protein, ash, and lactose content was estimated as per the method (AOAC, 2000). Titratable acidity of milk was and $\mathrm{pH}$ value was curd/Dahi was prepared by using commercially available DVS culture and followed as per the method given by Aneja, Mathur, Chandan, and Banerjee (2002). The wood of Mango (Mangifera indica) and Guava (Psidium guajava) were collected and sized into 22-25 g samples. Woods were dried in an oven for $24 \mathrm{~h}$ at $70^{\circ} \mathrm{C}$.

\subsection{Preparation of Smoked Raita}

Raita samples were prepared by mixing Dahi and water at the ratio of $2: 1 \mathrm{v} / \mathrm{v}$ using a blender at $25^{\circ} \mathrm{C}$, followed by the addition of $1 \%$ common salt w/v. The raita was smoked by a traditional cold smoking method. Where, the raita filled in cups of $100 \mathrm{~g}$ was exposed to the smoke of guava and mango charcoal at appropriate timings $(2.5,5,7.5$, and $10 \mathrm{~min}$ ) in a closed chamber (desiccator). The desiccator was air-tight due to silica gel covering the opening so no leakage of smoke was observed. The wood charcoal was prepared by burning wood pieces for about 15 min. The spices such as asafetida $(0.2 \% \mathrm{w} / \mathrm{v})$ and cumin $(0.2 \% \mathrm{w} / \mathrm{v})$ were sprinkled over charcoal during smoking. The 
experiments were conducted in three independent batches. The proximate composition of the product such as moisture, fat, protein, lactose, and ash content was determined as per the method given by AOAC (2000).

\subsection{Measurement of Titratable Acidity and $p H$}

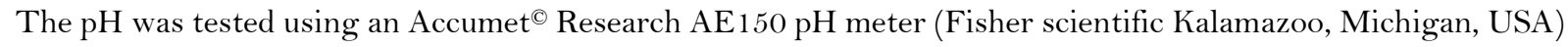
and titratable acidity (TA) was determined using $\mathrm{NaOH}\left(0.1 \mathrm{~mol} \cdot \mathrm{L}^{-1}\right)$ and phenolphthalein as an indicator.

\subsection{Total Phenolic Content}

The total phenolic content in raita was determined using the Folin-Ciocalteu method as given by Sandhya, Khamrui, Prasad, and Kumar (2018). $5 \mathrm{~g}$ of sample was diluted in $10 \mathrm{ml}$ distilled water. $100 \mu \mathrm{l}$ of the solution was taken in a falcon tube and $100 \mu \mathrm{l}$ of Folin reagent was added and kept undisturbed for $15 \mathrm{~min}$. After that $300 \mu \mathrm{l}$ of Sodium carbonate $(20 \% \mathrm{v} / \mathrm{v})$ was added and the mixture was incubated for 2 hours at $25^{\circ} \mathrm{C}$. The absorbance was read at $760 \mathrm{~nm}$ under a spectrometer (SHIMADZU UV-1800). Results obtained were expressed in milligram equivalents of gallic acid (GAE) based on the standard curve, where y stands for absorbance and $\mathrm{x}$ for phenolic concentration.

\subsection{Antioxidant Activity}

The DPPH (2,2- diphenyl-1-picrylhydrazyl) free radical scavenging activity method was performed to determine the antioxidant activity of smoked raita as given by Brand-Williams, Cuvelier, and Berset (1995). $1 \mathrm{~g}$ of sample was weighed in a falcon tube and mixed with $25 \mathrm{ml}$ of $60 \%$ methanol. This diluted sample of raita of $200 \mu \mathrm{l}$ was mixed with $2.9 \mathrm{ml}$ of $60 \mathrm{mM}$ DPPH working solution. A working solution of DPPH was prepared by mixing $3.94 \mathrm{mg}$ of DPPH in a 1 litre methanol solution. The mixture was kept in dark for 30 mins and the OD value was recorded in a spectrophotometer (SHIMADZU UV-1800) at $517 \mathrm{~nm}$. Methanol was used as a blank. The radical scavenging activity of the samples is expressed in terms of \% inhibition of DPPH absorbance.

$$
\text { Inhibition }=\frac{A_{c}-A_{t}}{A_{c}} \times 100
$$

Here, $A_{c}$ is the absorbance of controlled unsmoked raita.

$A_{t}$ is the absorbance of smoked raita.

\subsection{Color Analysis}

The evaluation of color of smoked raita was done using a colourflex instrument (Hunterlab, Hunter Associates Laboratory, Reston, Virginia, USA) with an in-built Universal software ${ }^{\circledR}$ (Ver. 4.10), and the results were expressed in terms of the CIELAB system. The instrument was calibrated with standard white and black reference tiles. The instrument was set at D65-artificial daylight $\left(10^{\circ}\right.$ standard angle) before taking readings. The sample was filled into a standardized glass cell up to $20 \mathrm{~mm}$ and placed on the port area (5cm diameter). The data was received in terms of $L^{*}$ (brightness to darkness), $a^{*}$ (greenness to redness), and $b^{*}$ (blueness to yellowness). The readings were taken in triplicate at $25{ }^{\circ} \mathrm{C}$. To calculate the browning index (BI) following equations were used (Bal, Kar, Satya, \& Naik, 2011).

$$
\begin{gathered}
z=\frac{\left(a^{*}+1.75 L^{*}\right)}{\left(5.645 L^{*}+a^{*}-3.012 b^{*}\right)} \\
\mathrm{BI}=\frac{(100(z-0.31))}{0.17}
\end{gathered}
$$

2.7. Sensory Evaluation of Smoked Raita

Raita samples were evaluated for color and appearance, flavor, acidity, body and texture, aroma, and overall acceptability. 15 panelists were asked for an evaluation of sensory characteristics including 12 males and 3 females. Alpha-numeric codes were used to mark the samples. The temperature of samples at the time of inspection was $15^{\circ} \mathrm{C}$ 
and a volume of $50 \mathrm{ml}$ inside clear sterile polypropylene-based jars. Panelists were asked to rate the samples on a 9point hedonic scale ( $9=$ like extremely, $8=$ like very much, $7=$ like moderately, $6=$ like slightly, $5=$ neither like nor a dislike, $4=$ dislike slightly, $3=$ Dislike moderately, $2=$ Dislike very much, $1=$ Dislike extremely). The experiment was conducted under broad daylight and at $27^{\circ} \mathrm{C}$ room temperature.

\subsection{Microbiological Analysis}

The total bacterial count was estimated using the pour plate method as described by Benson (2005). Serial dilution was done up to $10^{-7}$ using sterile saline solution ( $1 \%$ salt w/v). $1 \mathrm{ml}$ of each dilution was transferred into Petri plates and nutrient agar was poured into it. The plates were incubated at $37^{\circ} \mathrm{C}$ for $48 \mathrm{~h}$. The count was expressed as $\mathrm{cfu} / \mathrm{ml}$.

\subsection{Statistical Analysis}

The data obtained were statistically using one way analysis of variance (ANOVA) and a Duncan comparison test to estimate the significant difference between mean values at a $5 \%$ level of significance $(\mathrm{p}<0.05)$ by using the SPSS software tool (Ver.26).

\section{RESULTS AND DISCUSSIONS}

The proximate composition of raita is presented in Table 1.

Table 1. Composition of raita.

\begin{tabular}{l|c|c|c}
\hline Parameters & Control & Mango & Guava \\
\hline Total solids (\%) & $14.66 \pm 0.19$ & $14.18 \pm 0.13$ & $14.83 \pm 0.16$ \\
\hline Ash (\% WM) & $1.51 \pm 0.07$ & $1.51 \pm 0.06$ & $1.48 \pm 0.04$ \\
\hline Protein (\% WM) & $1.78 \pm 0.001$ & $1.78 \pm 0.002$ & $1.78 \pm 0.0007$ \\
\hline Fat (\% WM) & 4 & 4 & 4 \\
\hline
\end{tabular}

\subsection{Effect of Smoking on the Antioxidant Property of Raita}

The DPPH of raita samples treated with mango and guava wood charcoal at different time intervals is mentioned in Table 2. DPPH of treated raita samples had no significant difference $(\mathrm{P}>0.05)$ among themselves but were slightly higher than the control sample. The slight increase in DPPH in treated samples could be due to potential antioxidants such as carbonyls including reductones, furfural, and 5-methyl furfural (Huang, Ou, \& Prior, 2005; Namiki, 1988). Smoke contains ethyl alcohol, propyl alcohol, and isopropyl alcohol which subsequently oxidized to carbonyls (Ledesma, Rendueles, \& Díaz, 2015). However, most of the works of literature reported that antioxidant activity due to smoking is because of phenolic compounds (Shaiban, Al-Mamary, \& Al-Habori, 2006; Toth \& Potthast, 1984; Varlet, Serot, Cardinal, Knockaert, \& Prost, 2007). Smoke contains phenolic compounds such as orthocresol, metacresol, paracresol, guaiacol, methyl guaiacol, and xinelone, which also contribute to free radical scavenging activity. However, treated samples didn't show significant changes $(\mathrm{P}>0.05)$ in TPC content. It could be due to the shorter smoking time used during product preparation. Radical scavenging activity of the control sample can be credited to free sulfhydral (SH) groups of whey proteins and peptides resulting from the proteolytic activity, which influences the DPPH activity (Namdari \& Nejati, 2016; Tong, Sasaki, McClements, \& Decker, 2000).

\subsection{Effect of Smoking on Total Phenolic Content (TPC) of Raita}

TPC content of raita didn't show any significant changes $(\mathrm{P}>0.05)$ with an increase in smoking time Table 2. Our results are contradictory to the study reported on cheese smoked using Dodonia viscosa, Zizyphus spina christi and Acacia asak woods had three times higher TPC than the untreated samples (Shaiban et al., 2006). The cheese was smoked for a longer period; hence, the polyphenols content could be increased. The presence of phenolic compounds 
is also reported in Frankfurter-type sausages and mini salamis smoked with oak, poplar, hickory, spruce, fir, alder, and beech woods (Hitzel, Pöhlmann, Schwägele, Speer, \& Jira, 2013). Several factors affect the phenol content of smoke such as type of wood, smoking method, the degree of combustion, and the accessibility of air (Arseculeratne, Samarajeewa, \& Welianga, 1976; Arvanitoyannis \& Kotsanopoulos, 2012). The control sample also showed the presence of total phenolic content. It could be due to the presence of milk proteins such as whey proteins, which contributed to antioxidant activity (Dubeau, Samson, \& Tajmir-Riahi, 2010). Vázquez et al. (2015) reported that milk also contains several phenolic components. However, the author also mentioned that milk contains reducing compounds (iron II, bisulfite, sulfide, cyanide, nitrite, fructose, amine, etc.) which may interact with Folin- Ciocalteu reagent and contribute to total phenolic content. Tsen et al. (2014) reported that equol, a metabolite of daidzein, is a major phenolic compound in milk.

Table 2. properties of raita.

\begin{tabular}{|c|c|c|c|c|c|c|}
\hline Parameter & Wood & Control & $2.5 \mathrm{~min}$ & $5 \mathrm{~min}$ & $7.5 \mathrm{~min}$ & $10 \mathrm{~min}$ \\
\hline \multirow[t]{2}{*}{ DPPH (\%) } & Mango & \multirow[t]{2}{*}{$18.94 \pm 0.51^{\mathrm{a}}$} & $19.58 \pm 1.57^{\mathrm{aA}}$ & $18.98 \pm 0.083^{\mathrm{aA}}$ & $18.95 \pm 1.63^{\mathrm{aA}}$ & $18.80 \pm 0.73^{\mathrm{aA}}$ \\
\hline & Guava & & $20.38 \pm 3.29^{\mathrm{aA}}$ & $20.05 \pm 0.76^{\mathrm{aA}}$ & $19.03 \pm 0.26^{\mathrm{aA}}$ & $19.81 \pm 0.05^{\mathrm{aA}}$ \\
\hline \multirow[t]{2}{*}{ TPC (mg/g) } & Mango & \multirow[t]{2}{*}{$1.91 \pm 0.15^{\mathrm{a}}$} & $1.83 \pm 0.68^{\mathrm{aA}}$ & $2.07 \pm 0.40^{\mathrm{aA}}$ & $2.05 \pm 0.92^{\mathrm{aA}}$ & $1.78 \pm 0.55^{\mathrm{aA}}$ \\
\hline & Guava & & $1.89 \pm 0.26^{\mathrm{aA}}$ & $1.81 \pm 0.20^{\mathrm{bcA}}$ & $1.96 \pm 0.07^{\mathrm{cA}}$ & $1.79 \pm 0.05^{\mathrm{abcA}}$ \\
\hline \multirow[t]{2}{*}{$\mathrm{pH}$} & Mango & \multirow[t]{2}{*}{$4.63 \pm 0.01^{\mathrm{a}}$} & $4.45 \pm 0.005^{\mathrm{bcA}}$ & $4.43 \pm 0.08^{\mathrm{aA}}$ & $4.46 \pm 0.005^{\mathrm{bA}}$ & $4.44 \pm 0.00^{\mathrm{cdA}}$ \\
\hline & Guava & & $4.55 \pm 0.02^{\mathrm{bB}}$ & $4.53 \pm 0.01^{\mathrm{abB}}$ & $4.53 \pm 0.02^{\mathrm{abB}}$ & $4.50 \pm 0.00^{\mathrm{aB}}$ \\
\hline \multirow[t]{2}{*}{ TA (\%) } & Mango & \multirow[t]{2}{*}{$0.73 \pm 0.005^{\mathrm{a}}$} & $0.73 \pm 0.005^{\mathrm{aA}}$ & $0.74 \pm 0.00^{\mathrm{aA}}$ & $0.73 \pm 0.005^{\mathrm{aA}}$ & $0.74 \pm 0.00^{\mathrm{aA}}$ \\
\hline & Guava & & $0.70 \pm 0.005^{\mathrm{aB}}$ & $0.74 \pm 0.01^{\mathrm{bA}}$ & $0.70 \pm 0.005^{\mathrm{aB}}$ & $0.70 \pm 0.01^{\mathrm{aB}}$ \\
\hline \multirow[t]{2}{*}{ L* } & Mango & \multirow[t]{2}{*}{$83.42 \pm 0.46^{\mathrm{a}}$} & $83.71 \pm 0.11^{\mathrm{aA}}$ & $84.20 \pm 0.09^{\mathrm{bA}}$ & $84.23 \pm 0.04^{\mathrm{bA}}$ & $84.25 \pm 0.18^{\mathrm{bA}}$ \\
\hline & Guava & & $84.85 \pm 0.22^{\mathrm{cB}}$ & $84.38 \pm 0.18^{\text {bcA }}$ & $84.43 \pm 0.07^{\mathrm{bcA}}$ & $84.23 \pm 0.11^{\mathrm{bA}}$ \\
\hline \multirow[t]{2}{*}{$\mathrm{a}^{*}$} & Mango & \multirow[t]{2}{*}{$-2.40 \pm 0.17^{\mathrm{a}}$} & $-2.45 \pm 0.06^{\mathrm{aA}}$ & $-2.59 \pm 0.02^{\mathrm{aA}}$ & $-2.59 \pm 0.06^{\mathrm{aA}}$ & $2.55 \pm 0.15^{\mathrm{aA}}$ \\
\hline & Guava & & $-2.55 \pm 0.15^{\mathrm{aA}}$ & $-2.71 \pm 0.02^{\mathrm{bB}}$ & $-2.65 \pm 0.08^{\mathrm{bA}}$ & $2.67 \pm 0.00^{\mathrm{bB}}$ \\
\hline \multirow[t]{2}{*}{$\mathrm{b}^{*}$} & Mango & \multirow[t]{2}{*}{$3.73 \pm 0.02^{\mathrm{a}}$} & $6.54 \pm 0.15^{\mathrm{bA}}$ & $8.15 \pm 0.09^{\mathrm{dA}}$ & $7.70 \pm 0.11^{\mathrm{cA}}$ & $8.07 \pm 0.16^{\mathrm{dA}}$ \\
\hline & Guava & & $7.52 \pm 0.08^{\mathrm{cB}}$ & $6.89 \pm 0.35^{\mathrm{bB}}$ & $7.89 \pm 0.06^{\mathrm{dB}}$ & $7.09 \pm 0.05^{\mathrm{bB}}$ \\
\hline \multirow[t]{2}{*}{ Browning Index } & Mango & \multirow[t]{2}{*}{$2.73 \pm 0.15^{\mathrm{a}}$} & $5.79 \pm 0.17^{\mathrm{bA}}$ & $7.61 \pm 0.10^{\mathrm{dA}}$ & $7.07 \pm 0.09^{\mathrm{cA}}$ & $7.57 \pm 0.32^{\mathrm{dA}}$ \\
\hline & Guava & & $6.58 \pm 0.09^{\mathrm{cB}}$ & $6.13 \pm 0.41^{\mathrm{bB}}$ & $7.20 \pm 0.09^{\mathrm{dA}}$ & $6.22 \pm 0.05^{\mathrm{bB}}$ \\
\hline \multirow[t]{2}{*}{ Overall Acceptability } & Mango & \multirow[t]{2}{*}{$7.66 \pm 0.75^{\mathrm{a}}$} & $7.62 \pm 0.51^{\mathrm{aA}}$ & $7.87 \pm 0.44^{\mathrm{aA}}$ & $8.50 \pm 0.46^{\mathrm{bA}}$ & $7.62 \pm 0.58^{\mathrm{abA}}$ \\
\hline & Guava & & $7.70 \pm 0.97^{\mathrm{aA}}$ & $7.83 \pm 1.15^{\mathrm{aA}}$ & $8.25 \pm 0.95^{\mathrm{aA}}$ & $7.60 \pm 0.65^{\mathrm{aA}}$ \\
\hline \multirow[t]{2}{*}{ Colour and Appearance } & Mango & \multirow[t]{2}{*}{$7.43 \pm 0.62^{\mathrm{ab}}$} & $7.50 \pm 0.46^{\mathrm{aA}}$ & $7.62 \pm 0.74^{\mathrm{aA}}$ & $7.75 \pm 0.7 \mathrm{O}^{\mathrm{aA}}$ & $7.40 \pm 1.06^{\mathrm{aA}}$ \\
\hline & Guava & & $6.81 \pm 1.06^{\mathrm{aA}}$ & $7.37 \pm 0.51^{\mathrm{abA}}$ & $7.62 \pm 0.51^{\mathrm{bA}}$ & $7.50 \pm 0.53^{\mathrm{abA}}$ \\
\hline \multirow[t]{2}{*}{ Flavour } & Mango & \multirow[t]{2}{*}{$7.75 \pm 1.28^{\mathrm{ab}}$} & $7.62 \pm 0.74^{\mathrm{bA}}$ & $6.62 \pm 1.40^{\mathrm{aA}}$ & $7.31 \pm 0.7 \mathrm{O}^{\mathrm{abA}}$ & $7.75 \pm 0.7 \mathrm{O}^{\mathrm{bA}}$ \\
\hline & Guava & & $7.37 \pm 0.79^{\mathrm{aA}}$ & $6.93 \pm 1.42^{\mathrm{aA}}$ & $7.75 \pm 0.70^{\mathrm{aA}}$ & $6.62 \pm 1.40^{\mathrm{aA}}$ \\
\hline \multirow[t]{2}{*}{ Acidity } & Mango & \multirow[t]{2}{*}{$7.37 \pm 0.74^{\mathrm{a}}$} & $7.07 \pm 0.18^{\mathrm{abA}}$ & $7.16 \pm 0.75^{\mathrm{abA}}$ & $7.14 \pm 0.69^{\mathrm{abA}}$ & $7.10 \pm 0.50^{\mathrm{bA}}$ \\
\hline & Guava & & $7.43 \pm 0.49^{\mathrm{aA}}$ & $7.43 \pm 0.62^{\mathrm{aA}}$ & $7.31 \pm 0.7 \mathrm{O}^{\mathrm{aA}}$ & $7.31 \pm 0.70^{\mathrm{aA}}$ \\
\hline \multirow[t]{2}{*}{ Body and Texture } & Mango & \multirow[t]{2}{*}{$7.78 \pm 0.69^{\mathrm{a}}$} & $7.50 \pm 0.40^{\mathrm{aA}}$ & $7.50 \pm 0.40^{\mathrm{aA}}$ & $7.50 \pm 0.5 \mathrm{O}^{\mathrm{aA}}$ & $7.28 \pm 0.75^{\mathrm{aA}}$ \\
\hline & Guava & & $7.14 \pm 0.69^{\mathrm{aA}}$ & $7.14 \pm 0.69^{\mathrm{aA}}$ & $7.28 \pm 0.75^{\mathrm{aA}}$ & $6.85 \pm 1.06^{\mathrm{aA}}$ \\
\hline \multirow[t]{2}{*}{ Aroma } & Mango & \multirow[t]{2}{*}{$7.66 \pm 0.51^{\mathrm{a}}$} & $7.57 \pm 0.44^{\mathrm{abA}}$ & $7.42 \pm 0.53^{\mathrm{abA}}$ & $7.78 \pm 0.69^{\mathrm{bA}}$ & $7.42 \pm 0.44^{\mathrm{abA}}$ \\
\hline & Guava & & $7.42 \pm 1.13^{\mathrm{aA}}$ & $7.25 \pm 0.88^{\mathrm{aA}}$ & $7.78 \pm 0.69^{\mathrm{aA}}$ & $7.50 \pm 0.83^{\mathrm{aA}}$ \\
\hline
\end{tabular}

Note: abcd Values with different superscripts in a row represent statistical data significance $(\mathrm{P}<0.05)$.

${ }_{\mathrm{AB}}$ Values with different superscripts in a column represent statistical data significance $(\mathrm{P}<0.05)$.

\subsection{Effect of Smoking on Color Properties and Browning Index of Raita}

Color properties of raita samples are given in Table 2. Samples smoked with mango charcoal showed a significant increase $(\mathrm{P}<0.05)$ in $L^{*}$ and $b^{*}$ but no significant changes $(\mathrm{P}>0.05)$ in $a^{*}$. Whereas, guava smoke treated samples had a significant increase $(\mathrm{P}<0.05)$ in all color values. Moreover, the guava charcoal smoke treated samples had significantly higher $(\mathrm{P}<0.05) a^{*}$ and $b^{*}$ values than mango charcoal smoke treated samples. It was pretended that smoking will decrease the $L^{*}$ as like other smoked products like meat, fish, and cheese (Cais-Sokolińska, Lasik, \& Pikul, 2014; Ledesma et al., 2015). However, in the present investigation, the $L^{*}$ was increased slightly with mango and guava charcoal smoke treatment. It could be due to mixing the raita homogenously with a stirrer after smoking. Generally, smoking causes deposition of the brown layer on the product surface, although the internal portion of the product remains unaffected (Cais-Sokolińska et al., 2014). Mixing the product homogenously after smoking reduced the effect of smoking on color parameters. However, yellowness $\left(b^{*}\right)$ increased after smoking could be attributed to 
the dissolution of browning components. Browning index (BI) implies the presence of browning components in food products. Treated samples had significantly higher $(\mathrm{P}<0.05) \mathrm{BI}$ value than the control sample but did not follow any trend with change in treatment time.

\subsection{Effect of Smoking on Sensory Attributes of the Raita}

Sensory attributes of raita samples with different smoking times are given in Table 2. Smoking didn't show a significant $(\mathrm{P}>0.05)$ impact on the colour and appearance, acidity, and body and texture values of the raita. The colour of the smoked product was slightly yellow, it was at an acceptable level. However, flavor and aroma scores increased significantly $(\mathrm{P}<0.05)$ with an increase in smoking time till $7.5 \mathrm{~min}$ for both samples. The sensory panel perceived a mixture of smoked, slightly sour, piquant, and salt flavor in the smoked product. Majcher, Goderska, Pikul, and Jeleń (2011) reported similar kinds of flavor notes in smoked Oscypek cheese (Polish ewe cheese). They found several volatile compounds in smoked cheese such as phenolic compounds, furan/furanone group, alcohols, aldehydes, ketones, and esters. Phenols are the major volatile compounds responsible for smoky flavor in most smoked products (Cardinal, Cornet, Serot, \& Baron, 2006; Sérot, Baron, Knockaert, \& Vallet, 2004; Varlet et al., 2007). The sample who smoked for $7.5 \mathrm{~min}$ had higher overall acceptability scores and which is most preferred by the sensory panel. A similar kind of result was also reported for mozzarella cheese, where smoked mozzarella is considered most desirable than unsmoked one (Cais-Sokolińska et al., 2014). Similar kinds of results were also reported for smoked Cheddar and Swiss cheese (Riha \& Wendorff, 1993).

\subsection{Effect of Smoking and Storage Period on TA and pH of the Raita}

It can be seen from Table 2 that both smoked samples had no significant difference in TA and $\mathrm{pH}(\mathrm{P}>0.05)$ compared to control. It was anticipated to increase in acidity due to the presence of formic, acetic, and benzoic acids in smoke. Rahimzadeh, Tay, Mac Regenstein, Rokhzadi, and Dabiri (2020) reported that flavored yogurt drinks treated with liquid smoke didn't show a significant change in acidity and $\mathrm{pH}$ compared to the control product. However, Cais-Sokolińska et al. (2014) reported that smoked mozzarella had significantly greater active acidity than an unsmoked product. During the storage period, a significant reduction $(\mathrm{P}<0.05)$ in $\mathrm{pH}$ and a significant increase $(\mathrm{P}<0.05)$ in TA was seen till the $6^{\text {th }}$ day of storage Table 3. It could be due to the production of lactic acid by starter culture leading to an increase in acidity. However, Rahimzadeh et al. (2020) reported that no changes in TA and pH during storage of liquid smoke flavoured yogurt.

Table 3. Storage study.

\begin{tabular}{l|c|c|c|c|c}
\hline Parameter & Smoking & 0 days & 3 days & 6 days & 9 days \\
\hline \multirow{2}{*}{ TA (\%) } & Control & $0.72 \pm 0.005^{\mathrm{aA}}$ & $0.74 \pm 0.008^{\mathrm{bA}}$ & $0.76 \pm 0.005^{\mathrm{cA}}$ & $0.72 \pm 0.005^{\mathrm{aA}}$ \\
\cline { 2 - 5 } & Mango & $0.72 \pm 0.00^{\mathrm{aA}}$ & $0.72 \pm 0.003^{\mathrm{aB}}$ & $0.76 \pm 0.003^{\mathrm{cA}}$ & $0.73 \pm 0.005^{\mathrm{bC}}$ \\
\cline { 2 - 5 } & Guava & $0.74 \pm 0.005^{\mathrm{bB}}$ & $0.74 \pm 0.003^{\mathrm{bA}}$ & $0.75 \pm 0.002^{\mathrm{aB}}$ & $0.70 \pm 0.002^{\mathrm{cB}}$ \\
\hline \multirow{2}{*}{$\mathrm{pH}$} & Control & $4.33 \pm 0.01^{\mathrm{aA}}$ & $3.83 \pm 0.03^{\mathrm{cA}}$ & $3.55 \pm 0.009^{\mathrm{dA}}$ & $4.17 \pm 0.01^{\mathrm{bA}}$ \\
\cline { 2 - 5 } & Mango & $4.26 \pm 0.20^{\mathrm{aA}}$ & $3.82 \pm 0.02^{\mathrm{bA}}$ & $3.55 \pm 0.04^{\mathrm{cA}}$ & $4.26 \pm 0.00^{\mathrm{aB}}$ \\
\cline { 2 - 5 } & Guava & $4.26 \pm 0.03^{\mathrm{aA}}$ & $3.94 \pm 0.03^{\mathrm{bB}}$ & $3.50 \pm 0.002^{\mathrm{cA}}$ & $4.25 \pm 0.002^{\mathrm{aB}}$ \\
\hline \multirow{2}{*}{ SPC, $6^{\text {th }}$ Dilution $(\mathrm{CFU} / \mathrm{ml})$} & Control & $84.50 \pm 2.12^{\mathrm{aA}}$ & $77.00 \pm 1.41^{\mathrm{bA}}$ & $52.50 \pm 0.70^{\mathrm{cA}}$ & $50.00 \pm 4.24^{\mathrm{cA}}$ \\
\cline { 2 - 5 } & Mango & $39.50 \pm 2.12^{\mathrm{aB}}$ & $34.00 \pm 1.41^{\mathrm{abC}}$ & $32.50 \pm 2.12^{\mathrm{bB}}$ & $11.00 \pm 2.82^{\mathrm{cB}}$ \\
\cline { 2 - 5 } & Guava & $36.00 \pm 2.82^{\mathrm{bB}}$ & $47.00 \pm 1.41^{\mathrm{aB}}$ & $22.50 \pm 2.12^{\mathrm{cC}}$ & $19.00 \pm 5.65^{\mathrm{cC}}$ \\
\hline \multirow{2}{*}{$\mathrm{SPC}, 7^{\text {th }}$ Dilution $(\mathrm{CFU} / \mathrm{ml})$} & Control & $9.00 \pm 0.00^{\mathrm{aA}}$ & $8.00 \pm 0.00^{\mathrm{aA}}$ & $5.50 \pm 0.70^{\mathrm{bA}}$ & $5.50 \pm 0.70^{\mathrm{bA}}$ \\
\cline { 2 - 5 } & Mango & $3.50 \pm 0.70^{\mathrm{aC}}$ & $2.50 \pm 0.70^{\mathrm{aB}}$ & $3.50 \pm 0.70^{\mathrm{aB}}$ & $2.00 \pm 0.00^{\mathrm{aB}}$ \\
\cline { 2 - 5 } & Guava & $5.00 \pm 1.41^{\mathrm{aB}}$ & $3.00 \pm 0.00^{\mathrm{aB}}$ & $2.00 \pm 0.00^{\mathrm{bB}}$ & $2.50 \pm 0.70^{\mathrm{bB}}$ \\
\hline
\end{tabular}

Note: abc Values with different superscripts in a row represent statistical data significance $(\mathrm{P}<0.05)$.

ABC Values with different superscripts in a column represent statistical data significance $(\mathrm{P}<0.05)$.

\subsection{Effect of Storage Period on Microbial Properties of Raita}

Both guava and mango smoked raita had significantly less $(\mathrm{P}<0.05)$ microbial load than the control raita. Generally, smoke contains phenolic compounds, formaldehyde, carbonyls, and various acids. These substances have 
desirable bactericidal, antimicrobial, fungicidal, and preservative effects (Vaz-Velho, 2003). Majcher et al. (2011) reported that smoking of Ocsypek ewe cheese drastically reduced counts of lactococci, lactobacilli, streptococci, and enterococci and they assumed it was because of phenolic compounds. Rørvik (2000) also showed that the smoking of salmon leads to a reduction in counts of Listeria monocytogenes. However, as we realized from our analysis, the TPC and TA of the product were not at an appreciable level, therefore, it could be carbonyls that majorly played an antimicrobial role in raita. The BI of smoked samples was significantly higher than the control sample, hence it can be speculated that carbonyls compounds like furfural, 5-methyl furfural could be imparted antimicrobial activity. The antimicrobial activity of maillard reaction products is reported in several literatures (Chevalier, Chobert, Genot, \& Haertlé, 2001; Hauser, Müller, Sauer, Augner, \& Pischetsrieder, 2014; Rufián-Henares \& Morales, 2006). The SPC decreased significantly $(\mathrm{P}<0.05)$ with an increase in the storage period, it could be due to an increase in the acidity during storage.

\section{CONCLUSION}

Both guava and mango wood smoked raita samples had impressive sensory attributes compared control sample. The smoking time of $7.5 \mathrm{~min}$ is considered as an optimum for smoking of raita based on overall acceptability scores. The smoked product had excellent microbial quality and can expect better shelf life than the control product. However, the total phenolic content, antioxidant activity, titratable acidity, and pH did not differ from the control sample. Hence, the antimicrobial activity in the product was speculated to be carbonyl compounds absorbed during smoking.

Funding: This study received no specific financial support.

Competing Interests: The authors declare that they have no competing interests.

Authors' Contributions: All authors contributed equally to the conception and design of the study.

\section{REFERENCES}

Adeyeye, S. A. O. (2019). Smoking of fish: A critical review. Journal of Culinary Science Eீ Technology, 17(6), 559-575.Available at: https://doi.org/10.1080/15428052.2018.1495590.

Alasalvar, C., Miyashita, K., Shahidi, F., \& Wanasundara, U. (2011). Handbook of seafood quality, safety and health applications (pp. 349-350): John Wiley \& Sons.

Aneja, R. P., Mathur, B. N., Chandan, R. C., \& Banerjee, A. K. (2002). Technology of Indian milk products: Handbook on process technology modernization for professionals, entrepreneurs and scientists (pp. 160-169): Dairy India Yearbook.

AOAC. (2000). Official methods of analysis (17th ed.). Gaithersburg, MD, USA: The Association of Official Analytical Chemists.

Arseculeratne, S., Samarajeewa, U., \& Welianga, L. (1976). Inhibition of aflatoxin accumulation in smoked substrates. Journal of Applied Bacteriology, 41(2), 223-233.Available at: https://doi.org/10.1111/j.1365-2672.1976.tbo0623.x.

Arvanitoyannis, I. S., \& Kotsanopoulos, K. V. (2012). Smoking of fish and seafood: History, methods and effects on physical, nutritional and microbiological properties. Food and Bioprocess Technology, 5(3), 831-853.Available at: https://doi.org/10.1007/s 1 1947-011-0690-8.

Atanda, S. A., Adekalu, O. A., Agoda, S., Benson, O. B., \& Ihionu, G. C. (2015). The effect of wood type on the organoleptic properties of smoked Atlantic herring (Clupea harengus). NISEB Journal, 15(4), 137-141.

Bal, L. M., Kar, A., Satya, S., \& Naik, S. N. (2011). Kinetics of colour change of bamboo shoot slices during microwave drying. International Journal of Food Science Eீ Technology, 46(4), 827-833.Available at: https://doi.org/10.1111/j.1365$2621.2011 .02553 . x$

Benson, H. (2005). Microbial applications (9th ed., pp. 239-266). New York: McGraw Hill Higher Education.

Brand-Williams, W., Cuvelier, M.-E., \& Berset, C. (1995). Use of a free radical method to evaluate antioxidant activity. L $W T-F o o d$ Science and Technology, 28(1), 25-30.Available at: https://doi.org/10.1016/s0023-6438(95)80008-5. 
Cais-Sokolińska, D., Lasik, A., \& Pikul, J. (2014). Influence of water-soluble nitrogen and free amino groups on sensory attributes of smoked Mozzarella cheese. International Journal of Food Properties, 17(6), 1369-1378.Available at: https://doi.org/10.1080/10942912.2012.706854.

Cardinal, M., Cornet, J., Serot, T., \& Baron, R. (2006). Effects of the smoking process on odour characteristics of smoked herring (Clupea harengus) and relationships with phenolic compound content. Food Chemistry, 96(1), 137-146.Available at: https://doi.org/10.1016/j.foodchem.2005.02.040.

Chevalier, F., Chobert, J.-M., Genot, C., \& Haertlé, T. (2001). Scavenging of free radicals, antimicrobial, and cytotoxic activities of the Maillard reaction products of $\beta$-lactoglobulin glycated with several sugars. Journal of Agricultural and Food Chemistry, 49(10), 5031-5038.Available at: https://doi.org/10.1021/jfo 10549x.

Da Silva Cardoso, P., Fagundes, J. M., Couto, D. S., de Marchi Pires, E., Guimarães, C. E. D., Ribeiro, C. D. F., \& Otero, D. M. (2020). From curing to smoking: Processes and techniques for the production of pastrami. Brazilian Journal of Development, 6(8), 61511-61520.Available at: https://doi.org/10.34117/bjdv6n8-538.

Doe, K., Dali, F., \& Harmain, R. (2020). Evaluating the protein and fat content of skipjack (Katsuwonus pelamis) in the smoking process of arabushi. Paper presented at the IOP Conference Series: Earth and Environmental Science.

Dubeau, S., Samson, G., \& Tajmir-Riahi, H.-A. (2010). Dual effect of milk on the antioxidant capacity of green, Darjeeling, and English breakfast teas. Food Chemistry, 122(3), 539-545.Available at: https://doi.org/10.1016/j.foodchem.2010.03.005.

Hauser, C., Müller, U., Sauer, T., Augner, K., \& Pischetsrieder, M. (2014). Maillard reaction products as antimicrobial components for packaging films. Food Chemistry, 145, 608-613.Available at: https://doi.org/10.1016/j.foodchem.2013.08.083.

Hitzel, A., Pöhlmann, M., Schwägele, F., Speer, K., \& Jira, W. (2013). Polycyclic aromatic hydrocarbons (PAH) and phenolic substances in meat products smoked with different types of wood and smoking spices. Food Chemistry, 139(1-4), 955962.Available at: https://doi.org/10.1016/j.foodchem.2013.02.011.

Huang, D., Ou, B., \& Prior, R. L. (2005). The chemistry behind antioxidant capacity assays. Journal of Agricultural and Food Chemistry, 53(6), 1841-1856.Available at: https://doi.org/10.1021/jfo30723c.

Hui, Y. H., Nip, W. K., \& Rogers, R. (2001). Meat science and applications (pp. 5 10-516): CRC Press.

Ledesma, E., Rendueles, M., \& Díaz, M. (2015). Characterization of natural and synthetic casings and mechanism of BaP penetration in smoked meat products. Food Control, 51, 195-205.Available at: https://doi.org/10.1016/j.foodcont.2014.11.025.

Majcher, M., Ławrowski, P., \& Jeleń, H. (2010). Comparison of original and adulterated Oscypek cheese based on volatile and sensory profiles. European Social Sciences and Technology Alimentaria, 9(3), 265-275.

Majcher, M. A., Goderska, K., Pikul, J., \& Jeleń, H. H. (2011). Changes in volatile, sensory and microbial profiles during preparation of smoked ewe cheese. Journal of the Science of Food and Agriculture, 91(8), 1416-1423.Available at: https://doi.org/10.1002/jsfa.4326.

Margaret, M., \& Edgar, T. S. (2016). The effect of artisanal processing methods on lysine content in selected fish species from different lakes in Uganda. Agriculture \& Food Security, 5(1), 1-7.Available at: https://doi.org/10.1186/s40066-016-00726.

McGee, H. (2004). Wood smoke and charred wood. On Food and Cooking (Revised ed., pp. 448-450): Scribner.

Namdari, A., \& Nejati, F. (2016). Development of antioxidant activity during milk fermentation by wild isolates of lactobacillus helveticus. Applied Food Biotechnology, 3(3), 178-186.

Namiki, M. (1988). Chemistry of Maillard reactions: Recent studies on the browning reaction mechanism and the development of antioxidants and mutagens. Advances in Food Research, 32, 115-184.Available at: https://doi.org/10.1016/s00652628(08)60287-6.

Obodai, E., Muhammad, B., Obodai, G., \& Opoku, E. (2009). Effect of Fuel wood on the quality of smoked freshwater fish species sold in Tamale Central Market, Northern Region, Ghana. Ethiopian Journal of Environmental Studies and Management, 2(2), 1-9.Available at: https://doi.org/10.4314/ejesm.v2i2.45917. 
Rahimzadeh, G., Tay, A., Mac Regenstein, J., Rokhzadi, A., \& Dabiri, H. (2020). Evaluation of microbial and sensory properties of flavored yogurt drink produced by Noanea mucronata and liquid smoke treatment. Infectious Diseases and Herbal Medicine, 1(1), 5-10.Available at: https://doi.org/10.4081/idhm.2020.77.

Rehman, S. U., Farkye, N. Y., \& Drake, M. A. (2003). The effect of application of cold natural smoke on the ripening of cheddar cheese. Journal of Dairy Science, 86(6), 1910-1917.Available at: https://doi.org/10.3168/jds.s0022-0302(03)73777-1.

Riha, W., \& Wendorff, W. (1993). Evaluation of color in smoked cheese by sensory and objective methods. Journal of Dairy Science, 76(6), 1491-1497.Available at: https://doi.org/10.3168/jds.s0022-0302(93)77480-9.

Rørvik, L. M. (2000). Listeria monocytogenes in the smoked salmon industry. International Journal of Food Microbiology, 62(3), 183190.Available at: https://doi.org/10.1016/s0168-1605(00)00334-2.

Rufián-Henares, J. A., \& Morales, F. J. (2006). A new application of a commercial microtiter plate-based assay for assessing the antimicrobial activity of Maillard reaction products. Food Research International, 39(1), 33-39.Available at: https://doi.org/10.1016/j.foodres.2005.06.002.

Sandhya, S., Khamrui, K., Prasad, W., \& Kumar, M. (2018). Preparation of pomegranate peel extract powder and evaluation of its effect on functional properties and shelf life of curd. LWT, 92, 416-421.Available at: https://doi.org/10.1016/j.lwt.2018.02.057.

Sérot, T., Baron, R., Knockaert, C., \& Vallet, J. L. (2004). Effect of smoking processes on the contents of 10 major phenolic compounds in smoked fillets of herring (Cuplea harengus). Food Chemistry, 85(1), 111-120.Available at: https://doi.org/10.1016/j.foodchem.2003.06.011.

Shaiban, M., Al-Mamary, M., \& Al-Habori, M. (2006). Total antioxidant activity and total phenolic contents in Yemeni smoked cheese. Malaysian Journal of Nutrition, 12(1), 87-92.

Snow, A. R. (2010). Utilization of a liquid smoke fraction as a reactionary, caramel-type flavour in whipped cream applications via mallard reaction mechanisms. Manhattan, Kansas: Kansas University.

Sunen, E. (1998). Minimum inhibitory concentration of smoke wood extracts against spoilage and pathogenic micro-organisms associated with foods. Letters in Applied Microbiology, 27(1), 45-48.Available at: https://doi.org/10.1046/j.1472765x. 1998.00387.x.

Tong, L. M., Sasaki, S., McClements, D. J., \& Decker, E. A. (2000). Mechanisms of the antioxidant activity of a high molecular weight fraction of whey. Journal of Agricultural and Food Chemistry, 48(5), 1473-1478.Available at: https://doi.org/10.1021/jf991342v.

Toth, L., \& Potthast, K. (1984). Chemical aspects of the smoking of meat and meat products. Advances in Food Research, 29, 87158.Available at: https://doi.org/10.1016/So065-2628(08)60056-7.

Tsen, S. Y., Siew, J., Lau, E. K. L., Afiqah bte Roslee, F., Chan, H. M., \& Loke, W. M. (2014). Cow's milk as a dietary source of equol and phenolic antioxidants: Differential distribution in the milk aqueous and lipid fractions. Dairy Science $\mathcal{E}^{\circ}$ Technology, 94(6), 625-632.Available at: https://doi.org/10.1007/s13594-014-0183-4.

Varlet, V., Serot, T., Cardinal, M., Knockaert, C., \& Prost, C. (2007). Olfactometric determination of the most potent odor-active compounds in salmon muscle (Salmo salar) smoked by using four smoke generation techniques. Journal of Agricultural and Food Chemistry, 55(11), 4518-4525.Available at: https://doi.org/10.102 1/jfo63468f.

Vaz-Velho, M. (2003). Smoked foods/production. In: Caballero, B., Trugo, L.C., and Finglas, P.M. (Eds.), Encyclopedia of Food Sciences and Nutrition (pp. 5302-5309). Waltham, MA, USA: Academic Press (Elsevier Ltd.).

Vázquez, C. V., Rojas, M. G. V., Ramírez, C. A., Chávez-Servín, J. L., García-Gasca, T., Martínez, R. A. F., \& Castellote, A. I. (2015). Total phenolic compounds in milk from different species. Design of an extraction technique for quantification using the Folin-Ciocalteu method. Food Chemistry, 176, 480-486.Available at: https://doi.org/10.1016/j.foodchem.2014.12.050.

Views and opinions expressed in this article are the views and opinions of the author(s), Journal of Food Technology Research shall not be responsible or answerable for any loss, damage or liability etc. caused in relation to/arising out of the use of the content. 